\title{
THROMBOPHLEBITIS OF PREPUBIC VEINS IN PATIENT WITH APLASIA OF THE LEFT COMMON AND LEFT EXTERNAL ILIAC VEINS - CASE REPORT
}

\author{
Crnokrak Bogdan, Zdravkovic Darko, Toskovic Borislav, Colakovic Natasa \\ University Hospital Medical Center "Bežanijska kosa“, Belgrade
}

Primljen/Received 26. 11. 2019. god.

Abstract: Introduction: A congenital defect of some of the large veins that drain blood from the lower extremity is a very rare occurrence and, considering the clinical consequences, it is generally diagnosed at a relatively early age - in childhood or youth. Within the complex classification of vascular malformations, a special category is comprised of large blood vessel malformations, also called truncal vascular malformations. In comparison to other anomalies, aplasia or lack of development of a certain segment in the deep venous systems, potentially has the most serious hemodynamic consequences. The appearance of varicose veins, through which the venous blood is drained distally to the obstruction into an unusual area, such as the lower part of the trunk or the anterior abdominal wall, usually spurs the patient into action in terms of conducting diagnostic procedures so that diagnosis can be reached before complications occur. Defects of large magistral deep veins, which remain unrecognized until adulthood and which are diagnosed after complications in the drainage venous network occur, are infrequent. Complications that can arise in association with this malformation are manifested not only in varicosally altered collateral veins, but also in the venous drainage area peripherally from the obstruction.

Case report: We hereby present a case of a patient admitted to hospital with a clinical picture and an ultrasound finding indicating an incarcerated inguinal hernia. During surgery, thrombophlebitis of extremely dilated prepubic veins was established. Subsequent diagnostic procedures revealed the presence of a rare vascular anomaly - aplasia of the left common andleft external iliac veins. Under the mentioned conditions, a collateral venous network developed in both groins and the prepubic region, draining blood from the left leg into the right common femoral vein.
Prihvaćen/Accepted 25. 12. 2019. god.

Key words: Aplasia of the iliac vein, acute thrombophlebitis, varicosities of prepubic veins.

\section{INTRODUCTION}

Congenital vascular malformations can be defined as an embryologically formed, present at birth anomaly of vascular morphogenesis which leads to real structural disorders in the vascular system $(1,2)$. The classification of congenital vascular malformations was made by the International Society for the Study of Vascular Anomalies - ISSVA based on several criteria including anatomical, histological, physiological, pathological and genetic criteria (3). The last revision to the classification was made in 2018. All vascular anomalies are divided into two categories - vascular tumors and vascular malformations. Vascular malformations can be classified into four categories - simple vascular malformations, combined vascular malformations, malformations of large blood vessels (truncal vascular malformations) and vascular malformations associated with other anomalies (3).

Truncal vascular malformations in the deep venous system, which imply the absence or hypoplasia of a segment of the venous tree, are most often associated with the development of a rich collateral venous network that drains blood from the vascular area peripherally from the site of aplasia/hypoplasia towards the normal venous segment. Depending on the place of obstruction, as well as the capacity for collateral development in a certain anatomical region, this collateral network can exist only in the deep venous system, only in the superficial venous system, or in both the deep and the superficial venous system. Due to the increased blood flow and the inability to withstand the increased pressure because of their histological and anatomical features, the superficial veins included in the collateral 
venous network are usually subject to varicose changes over time. The extent and extensiveness of varicose vein development that form the drainage network of the area peripherally from the obstacle is unpredictable, but it is usually not pronounced in the first decade of life $(3,4)$.

We will present the case of a patient whose truncal vascular malformation - aplasia of the left external and the left common iliac veins, remained unrecognized until mature adulthood. The clinical manifestation that led to the diagnosis was highly unusual - thrombophlebitis in the collateral venous network in the anterior abdominal wall.

\section{CASE REPORT}

A 48-year-old male, smoker, of typical physical constitution (Body Mass Index 25.3) presented to the surgical emergency unit of the University Hospital Medical Center "Bežanijska kosa" with clinical signs of phlegmone in the suprapubic region (redness, pain, locally increased temperature and swelling).

The difficulties started two days earlier, with increased body temperature up to $37.8 \mathrm{C}$. Based on case history data, we discovered that he had a right-sided inguinal hernia surgery in his childhood. Four years earlier, the patient had phlebothrombosis in the deep venous system of the left leg, he was treated with the oral anticoagulant drug Acenocoumarol for 6 months, until a supposed complete recanalization in the deep venous system. No antiplatelet therapy was initiated after anticoagulant therapy was discontinued. The results of the tests for congenital and acquired thrombophilia (genetic analyses, protein $\mathrm{C}$, protein $\mathrm{S}$, Activated protein $\mathrm{C}$ resistance) performed in that period were negative. Since then, the patient has had swelling in the left leg. The patient did not report in his case history any information about the occurrence of dilated veins in other parts of his body except the legs.

The patient reported in the family history that his father passed away following a cerebrovascular insult.

In addition to the documentation from previous hospitalizations for phlebothrombosis and hematological tests, the patient's medical documentation also included a finding from an abdominal ultrasound examination performed earlier that day in another healthcare facility, which describes the presence of inguinal hernias on both sides, with suspected presence of intestinal loops in them.

Clinical examination revealed the presence of redness and painful induration of the size of a male fist in the right inguinal and suprapubic region.

Soft abdomen, insensitive to pain on palpation, except in the zones of the mentioned induration. The pedal, popliteal, and femoral pulses were palpable on both sides, there were varicose veins on the left lower leg with signs of old thrombophlebitis, as well as swelling in the left lower leg - the difference in circumference between the left and right lower legs on admission was $4 \mathrm{~cm}$. Early lipodermatoscleros was also present above the medial malleolus of the left leg; there was no active ulcer.

\section{CEAP classification Left leg C2,4b,S,Ec, As,d,Pr,o}

$$
\text { Right leg C2,4a,A, Es, As,d, Pr,o }
$$

Results of laboratory analyses on admission Le-8.3, Er-5.51, Hg-154, Hct-0.475, Tr-184, Urea-6.0, Creatinine-83, CRP-48.0

Native abdominal radiotomography showed no hydroaeric levels or pneumoperitoneum.

Abdominal ultrasound examination- bilaterally in the inguinal region, more to the left side under the skin, there are multiple tubular structures, $3-4 \mathrm{~cm}$ in diameter, appearing as aperistaltic intestinal loops, the structures closer to the left groin being wider and those closer to the right groin narrower.

Due to suspected incarcerated inguinal hernia with suspected bowel perforation and phlegmon of the anterior abdominal wall, surgical treatment was indicated and preoperative preparation of the patient was carried out.

The surgery was performed under general endotracheal anesthesia with the approach for classic right-sided inguinal hernia surgery. A mass of thrombosed varicose veins with diameter ranging from 1 to 3 $\mathrm{cm}$ was found in the subcutaneous tissue. Thrombosed veins filled the prepubic region and the thrombosis propagated into the superficial epigastric vein to the right, which is about $3.5 \mathrm{~cm}$ in diameter in height of the inguinal ligament. The surgery was completed with exploration.

Postoperatively, therapeutic doses of low-molecular-weight Heparin were administered to the patient, compression bandages were placed on both legs, and the leg was elevated.

On the first postoperative day, the superficial and deep venous systems of both legs were explored by ultrasound that showed presence of thrombosis on the left, thrombophlebitis was found in the great saphenous vein from the sapheno-femoral junction to below the knee. In the deep veins, phlebothrombosis was found in the common femoral vein and in the deep femoral vein up to about $8 \mathrm{~cm}$ below the inguinal ligament. The superficial femoral vein showed no signs of thrombosis. Thrombosis was present in the left popliteal vein and the posterior tibial vein with peripheral recanalization of about $25 \%$. On the right, thrombosis was present in the popliteal vein and posterior tibial vein. 
The hematologist, after examining the patient, agreed to introduce anticoagulant therapy.

Due to suspected organic obstruction to venous blood flow in the lesser pelvis, which caused the development of venous collaterals, MDCT of the abdomen and the lesser pelvis with angiography was carried out and showed that the left external and the left common iliac veins were reduced to a thin fibrous band without flow, which can be traced to the common femoral vein. The internal left iliac vein drained directly into the inferior vena cava. Complete drainage of venous blood from the left leg is carried out via the collateral, partly via subcutaneous venous collaterals formed in the left
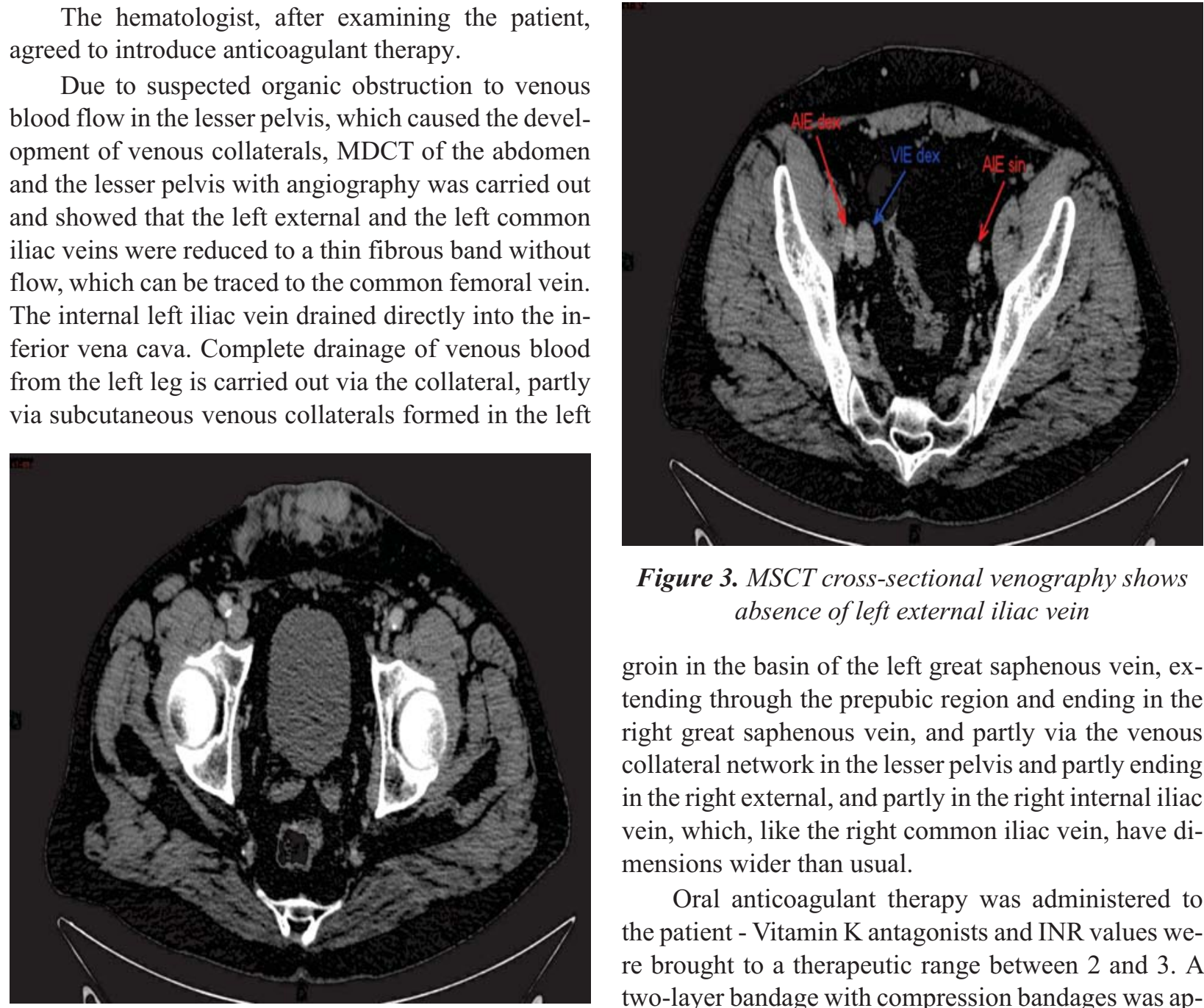

Figure 3. MSCT cross-sectional venography shows absence of left external iliac vein

groin in the basin of the left great saphenous vein, extending through the prepubic region and ending in the right great saphenous vein, and partly via the venous collateral network in the lesser pelvis and partly ending in the right external, and partly in the right internal iliac vein, which, like the right common iliac vein, have dimensions wider than usual.

Oral anticoagulant therapy was administered to the patient - Vitamin K antagonists and INR values were brought to a therapeutic range between 2 and 3. A two-layer bandage with compression bandages was ap-

Figure 1. MDCT shows thrombophlebitis and phlegmon in the prepubic region

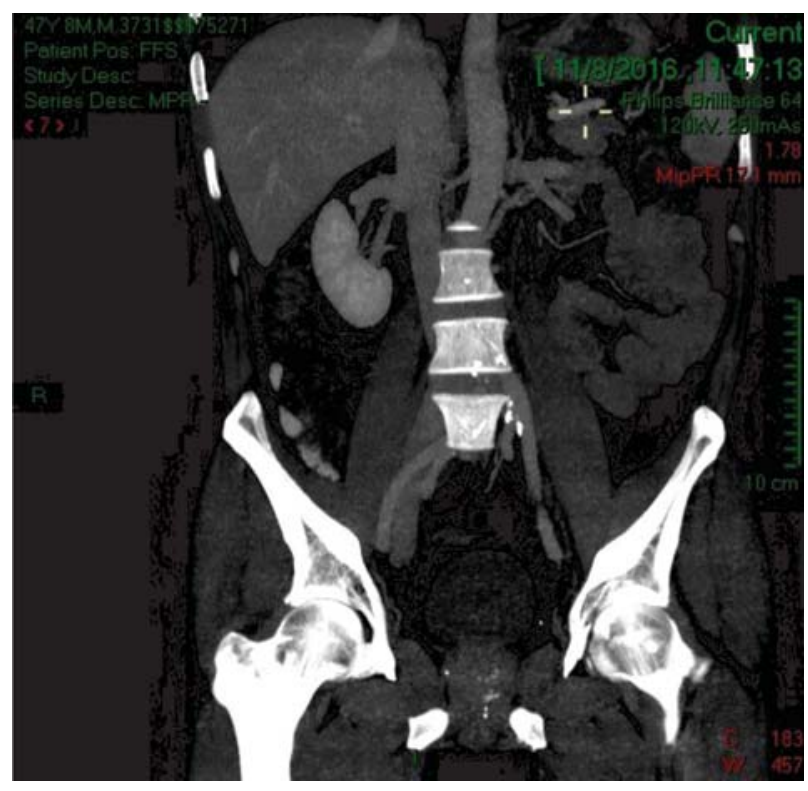
plied to reduce leg swelling. Pads with boric acid solution were applied locally at the site of thrombophlebitis. During first $24 \mathrm{~h}$ after surgery, at 6-hour intervals, the arterial status on the left leg was evaluated by palpation of the pulses over the magistral arteries of the leg and foot, and the circumference of the lower and upper legs was monitored for a timely diagnosis of possible development of compartment syndrome on the left lower leg.

On the seventh day after admission to the hospital, regression of the leg swelling was verified, which continued during the following days, and the patient was mobilized. When it became clear from the improvement trend of the local status on the left leg that there was no risk of developing new complications, with INR values in the therapeutic range, the patient was discharged to further home health care.

The follow-up examination one month after the patient was discharged from the hospital revealed a partial recanalization of thrombophlebitis in the prepubic and inguinal veins with absence of redness and painful sensitivity, but still present in duration of both groins and prepubic region. 
The follow-up examination after 3 months showed no redness, induration, or pain sensitivity in the groin and prepubescent region, but the mass of compressible varicose veins was palpable.

The follow-up examinations after 6 months and one year showed that with the taken therapeutic measures, there was no progression of chronic venous insufficiency, left lower leg swelling was not in progression, there was no progression of lipodermatosclerosis, there was no active ulcer. The therapeutic compression stocking, of compression grade 3 , was replaced by the patient every 6 months in the previous period.

Due to the risk of new phlebothrombosis in the deep veins of the legs or thrombophlebitis in the drainage venous system, oral anticoagulant therapy was not discontinued.

\section{DISCUSSION AND CONCLUSION}

Aplasia/hypoplasia of the magistral venous segment with development of collateral venous network in the subcutaneous tissue, is a rare condition that is most commonly recognized in childhood or early youth, and depending on its extensiveness and possible hemodynamic consequences, therapy is determined in order to prevent or at least slow down the development of chronic venous insufficiency. The occurrence of extensive varicose veins in subcutaneous tissue in an unusual region in younger patients should raise clinical suspicion of a vascular anomaly. Aplasia of the magistral vein can affect only one part of the vein or the entire vein, and even multiple veins, which is actually the reason for the unpredictable course of the disease, the occurrence of complications and the rapid progression of chronic venous insufficiency. Changes in tissues and organs over time occur peripherally from the obstruction to venous blood flow. If the drainage area below the obstruction also includes the lower extremities, the edema in the lower parts of the lower leg is always the first sign of chronic venous insufficiency development. These changes are generally accompanied by varicosities occurringin the superficial venous segment of the diseased leg, which becomes a visual manifestation of malformation and a reason for diagnostic tests that can lead to the right diagnosis. It is important to be aware of the possible existence of venous vascular malformation, which is the reason for the occurrence of varicose veins in the first decades of life, since removal of these veins without insight into the condition of the deep venous network can cause worsening of venous insufficiency. For this reason, it is important to be certain that the deep venous network is complete prior to operative removal of any varicosally altered superficial venous segment.
Complications that develop in patients with truncal venous malformation can be divided into two groups, one referring to changes and complications that occur in the area distal to the obstruction and they can relate to the veins themselves beneath the obstruction, in terms of appearance of phlebothrombosis and thrombophlebitis, and development of varicose veins in that area, or they can relate to organs and tissues in the drainage area of these veins in terms of appearance of edema, stasis dermatitis, lipodermatosclerosis and active venous ulcer, all as manifestations of chronic venous insufficiency. The dynamics of the development of these complications is unpredictable and depends on other factors, such as physical activity and constitution. The second group of complications is related to varicose veins through which blood is drained from the area below the obstruction and they are indistinguishable from complications that can occur in any varicose vein. The most common complication is surely thrombophlebitis, whereas the occurrence of spontaneous vein rupture is very rare.

In this case, it was an emergency condition - the phlegmons of the anterior abdominal wall, which was preoperatively subjected to minimum diagnostic processing insufficient to make accurate diagnosis of the condition preoperatively. The existence of a serious problem in the deep venous system in the lesser pelvis with development of varicosities in the anterior abdominal wall representing the collateral drainage venous network of one extremity, was suspected during surgery by observing extremely dilated thrombosed varicosities connecting the systems of the left and right great saphenous veins via the superficial epigastric vein and venous network of the lower part of the anterior abdominal wall. The surgery itself was insufficient to determine the cause of the problem, and the differential diagnosis could be several congenital or acquired conditions that could have led to chronic obstruction of the vein flow in the lesser pelvis (aplasia or hypoplasia in the venous system; benign and malignant tumors in the pelvis).

Although the inflammatory process caused by acute thrombophlebitis manifested as extensive phlegmon of the anterior abdominal wall was the main reason for surgical treatment, the removal of thrombosed varicose veins was not taken into consideration as a treatment option. Thrombovaricectomy would damage the venous network via which the blood bypasses the obstruction in the flow, which can lead to deterioration of the condition in the extremity (ies), acutely in terms of developing venous compartment syndrome, or chronically in terms of worsening of chronic venous insufficiency. A postoperative CT scan verified the existence of aplasia of the external 
and common iliac veins on the left side, thus confirming that the decision not to remove thrombosed varicose veins was the right one.

All patients diagnosed with congenital absence of a certain venous segment should be familiarize with the possible course of the disease and the occurrence of possible complications, as well as the measures that must be taken to mitigate the consequences of this rare anomaly.

The effects of adequate conservative treatment, such as maintaining optimal values of the body mass index, moderate physical activity, compression therapy in the area of potential development of chronic venous insufficiency and care of the skin exposed to edema, should not be underestimated.

Each patient for whom surgical removal of varicose veins is planned, must undergo diagnostic procedures that need to assure us of the continuity of the deep venous tree. In case thrombophlebitis in the drainage venous network occurs, it is necessary to avoid the removal of thrombosed varicose veins as this can make it difficult to derive blood from the segment peripheral from the site of aplasia/hypoplasia. The significance of maintaining the integrity of the existing venous network is indisputable, but the need to introduce anticoagulant or antiplatelet therapy should be considered for each patient individually. In case thrombophlebitis or phlebothrombosis occur, it is necessary to carry out a complete hematological examination in terms of congenital or acquired thrombophilia.

The effect of the taken conservative measures should be actively evaluated in each case, and if it is found that they are insufficient, the possibility of surgical reconstruction of the missing venous segment should be considered.

Conflict of Interests: The authors declare that there are no conflicts of interest related to this article.

Funding: None

\section{Licensing}

This work is licensed under a Creative Commons Attribution 4.0 International (CC BY 4.0) License.

\title{
Sažetak
}

\section{TROMBOFLEBITIS PREPUBIČNIH VENASA APLAZIJOM LEVE ZAJEDNIČKE I LEVE SPOLJAŠNJE ILIJAČNE VENE - PRIKAZ SLUČAJA}

\author{
Crnokrak Bogdan, Zdravković Darko, Tošković Borislav, Čolaković Nataša \\ University Hospital Medical Center "Bežanijska kosa“, Belgrade
}

Uvod: Kongenitalni defekt neke od velikih vena, koja drenira krv iz donjih ekstermiteta je veoma retka bolest, a razmatrajući kliničke posledice, moglo bi se reći da se ova bolest generalno dijagnostikuje u relativno ranom uzrastu - u dečijem uzrastu ili u adolescenciji. U okviru kompleksne klasifikacije vaskularnih malformacija, posebna kategorija je sastavljena od velikih krvnih sudova, koji se nazivaju trunkalne vaskularne malformacije. U poređenju sa ostalim anomalijama aplazija ili nedostatak razvoja pojedinih segmenata u sistemu dubokih vena, može imati značajne hemodinamske posledice. Izgled varikoznih vena, kroz koji se drenira distalno od opstrukcije u regiju u koju se obično ne drenira krv,kao što su donji delovi tela ili prednji trbšni zid, obično navodi pacijenta da «nešto nije u redu», nakon čega se javlja lekaru i započinje se sprovođenje dijagnostičkih procedura, tako da dijagnoze mogu biti postavljene pre nego što se dese komplikacije. Defekti velikih magistalnih dubokih vena, koje ostaju neprepoznate do odraslog do- ba i koje se dijagnostikuju nakon pojave komplikacija u okviru venske mreže, i nisu toliko česte. Komplikacije koje su povezane sa ovim malformacijama ne manifestuju se samo u varikozno izmenjenim kolateralnim sudovima, nego i u venskoj drenaži periferno od opstrukcije. Prikaz slučaja: Ovom studijom prikazujemo pacijena, koji je hospitalizovan sa kliničkom slikom inkarcerirane ingvinalne hernije, koja je potvrđena i ultrazvučnim pregledom. Tokom hirurške procedure utvrđeno je postojanje tromboflebitisa ektremno dilatiranih prepubičnih vena. Naknadno sprovedenim dijagnostičkim procedurama utvrđeno je prisustvo retke vaskularne anomalije - aplazija leve zajedničke, kao i leve spoljne ilijačne vene. Spomenutim dijagnostičkim procedurama utvrđeno je postojanje kolateralne venske mreže koja se razvila u obe prepone i prepubičnoj regiji, koje dreniraju krv iz leve noge u desnu zajedničku femoralnu venu.

Ključne reči: aplazija ilijačne vene, akutni tromboflebitis, varikoziteti prepubičnih vena. 


\section{REFERENCES}

1. Mulliken JB, Glowacki J. Hemangiomas and vascular malformations in infants and children: a classification based on endothelial characteristics. Plast Reconstr Surg. 1982; 69(3): 412-20.

2. Young AE. Pathogenesis of vascular malformations. In: Mulliken JB, Young AE, editors. Vascular birthmarks: hemangiomas and malformations. Philadelphia: W.B. Saunders Co, 1988. p. 107-13.
3. Wassef M, Blei F, Adams D, Alomari A, Baselga E, Berenstein A, et al. Vascular anomalies classification: recommendations from the International Society for the Study of Vascular Anomalies. Pediatrics. 2015; 136(01): e203-e14

4. Kennedy WP: Epidemiologic aspects of the problem of congenital malformations. Persaud TNV Problems of Birth Defects. 1977 Publisher University Park Press Baltimore Maryland $35-52$.

\section{Correspondence to/Autor za korespondenciju}

Bogdan Crnokrak

University Hospital Medical Center "Bežanijska kosa“, Belgrade

Bezanijska kosa

11080 Belgrade, Serbia

email: bcrnokrak@yahoo.com 